\title{
PENGGUNAAN SISTEM SANKSI PIDANA PADA PELAKU TINDAK PIDANA KORPORASI
}

\author{
AHMAD \\ Sekolah Tinggi Ilmu Hukum Putri Maharaja Payakumbuh \\ ahmad@gmail.com
}

\begin{abstract}
The acceptance of the corporation as a subject of criminal law who is considered to be able to commit a criminal act and can be criminally responsible for it will of course lead to other consequences in its application. Various consequences or problems that can arise are reflected in the question of getting a death penalty or imprisonment as regulated in article 10 of the Criminal Code which is applied to a corporation. Or can the "corporate death penalty" and "corporate imprisonment" as stated by Brickey be regarded as a death penalty or imprisonment for a corporation? When compared with the provisions in Law Number 31 of 1999 as amended by Law Number 20 of 2001 concerning the Eradication of Criminal Acts of Corruption, precisely in article 2 paragraph (2) and article 18 paragraph (1) point c and point $d$ According to this law, in the author's opinion, basically the "corporate death penalty" as stated by Brickey is the same as the provisions of "all or part of the company closure" and "corporate imprisonment" which is basically the same as the provision of "all or part revocation of certain rights or elimination of all or part of certain profits" as regulated in Article 18 paragraph (1) point $c$ and point $d$ of this Law. In addition, if you look at the provisions in Article 2 paragraph (2) which states that: "In the case of a criminal act of corruption as referred to in paragraph (1) carried out under certain circumstances, the death penalty can be imposed". And when viewed from the explanation it is stipulated that: "what is meant by "certain circumstances" is if the crime is committed against funds for overcoming dangerous conditions, national natural disasters, overcoming the consequences of widespread social unrest, overcoming economic crises, and occurring repetition of corruption.
\end{abstract}

Keywords: System, Criminal Sanctions, Criminal Actors, Corporations.

Abstrak: Diterimanya korporasi sebagai subjek hukum pidana yang dinilai dapat melakukan tindak pidana dan dapat mempertanggungjawabkannya secara pidana sudah tentu akan menimbulkan konsekuensi lain dalam penerapannya. Berbagai konsekuensi atau masalah yang dapat muncul tercermin dalam pertanyaan dapatkan pidana mati atau pidana penjara sebagaimana diatur dalam pasal 10 KUHP diterapkan terhadap suatu korporasi. Atau apakah "corporate death penalty" dan "corporate imprisonment" sebagaimana dikemukakan oleh Brickey dapat dikatakan sebagai penjatuhan pidana mati atau pidana penjara bagi suatu korporasi? Apabila dibandingkan dengan ketentuan yang ada dalam Undang-Undang Nomor 31 tahun 1999 sebagaimana telah diubah oleh Undang-Undang Nomor 20 tahun 2001 tentang Pemberantasan Tindak Pidana Korupsi tepatnya dalam pasal 2 ayat (2) dan pasal 18 ayat (1) poin $\mathrm{c}$ dan poin $\mathrm{d}$ Undang-Undang ini maka menurut hemat penulis, pada dasarnya "corporate death penalty" sebagaimana dikemukakan oleh Brickey sama dengan ketentuan "penutupan seluruh atau sebagian perusahaan" dan "corporate imprisonment" pada dasarnya sama dengan ketentuan "pencabutan seluruh atau sebagian hak-hak tertentu atau penghapusan seluruh atau sebagian keuntungan tertentu" sebagaimana diatur dalam pasal 18 ayat (1) poin c dan poin d Undang-Undang ini. Selain itu, apabila melihat ketentuan dalam pasal 2 ayat (2) yang menyatakan bahwa: "Dalam tindak pidana korupsi sebagaimana dimaksud dalam ayat (1) dilakukan dalam keadaan tertentu, pidana mati dapat dijatuhkan". Dan apabila dilihat dari penjelasannya diatur bahwa: "yang dimaksud dengan "keadaan tertentu" adalah apabila tindak pidana tersebut dilakukan terhadap dana-dana penanggulangan bagi penaggulangan keadaan bahaya, bencana alam nasional, penanggulangan terhadap akibat kerusuhan sosial yang meluas, penanggulangan krisis ekonomi, dan terjadi pengulangan tindak pidana korupsi”.

Kata Kunci: Sistem, Sanksi Pidana, Pelaku Tindak Pidana, Korporasi. 


\section{A. Pendahuluan}

Suatu kenyataan yang tidak bisa dipungkiri bahwa peran korporasi saat ini menjadi sangat penting dalam kehidupan masyarakat. Tujuan korporasi untuk terus meningkatkan keuntungan yang diperolehnya mengakibatkan sering terjadinya tindakan pelanggaran hukum (Suhariyono AR, 2009). Apapun jenis kejahatan yang dilakukan, korbanlah yang selalu menderita kerugian akibat kejahatan yang terjadi. Demikian juga kejahatan yang dilakukan oleh korporasi yang menimbulkan korban kejahatan korporasi yang menderita kerugian. Korban kejahatan korporasi cakupannya lebih luas daripada korban kejahatan pada umumnya baik dari segi jumlah korban maupun kerugian yang ditimbulkan, sehingga korban kejahatan korporasi perlu mendapat perhatian khusus dalam pencegahan dan penanggulangan kejahatan korporasi dalam hal ini berupa pertanggungjawaban pidana korporasi terhadap korban kejahatan korporasi (Bismar Nasution, 2019).

Kejahatan korporasi (corporate crime) merupakan salah satu wacana yang timbul dengan semakin majunya kegiatan perekenomian dan teknologi. Corporate crime bukanlah barang baru, melainkan barang lama yang senantiasa berganti kemasan. Tidak ada yang dapat menyangkal bahwa perkembangan zaman serta kemajuan peradaban dan teknologi turut disertai dengan perkembangan tindak kejahatan berserta kompleksitasnya (Singgih, 2005). Di sisi lain, ketentuan Hukum Pidana yang berlaku di Indonesia belum dapat menjangkaunya dan senantiasa ketinggalan untuk merumuskannya. Salah satu contohnya adalah Tindak Pidana Pencucian Uang (money laundering) yang baru dikriminalisasi secara resmi pada tahun 2002. Contoh lain adalah kejahatan dunia maya atau cyber crime yang baru diatur secara resmi dalam Undang-Undang Nomor 19 Tahun 2016 tentang Perubahan Atas Undang-undang Nomor 11 Tahun 2008 tentang Informasi dan Transaksi Elektronik juncto Undang-Undang 11 Tahun 2008 tentang Informasi dan Transaksi Elektronik. Akibatnya, banyak bermunculan tindakan-tindakan atau kasus-kasus illegal, namun tidak dapat dikategorikan sebagai crime.

Tindak pidana (crime) dapat diidentifikasi dengan timbulnya kerugian (harm), yang kemudian mengakibatkan lahirnya pertanggungjawaban pidana atau criminal liability (Hyman Gross, 1979). Pada gilirannya mengundang perdebatan adalah bagaimana pertanggungjawaban korporasi atau corporate liability mengingat bahwa di dalam Kitab Undang-undang Hukum Pidana (KUHP) Indonesia yang dianggap sebagai subyek hukum pidana hanyalah orang perseorangan dalam konotasi biologis yang alami (naturlijkee person). Di samping itu, KUHP juga masih menganut asas sociates delinquere non potest dimana badan hukum atau korporasi dianggap tidak dapat melakukan tindak pidana.

Sally. A. Simpson yang mengutip pendapat John Braithwaite menyatakan kejahatan korporasi adalah "conduct of a corporation, or employees acting on behalf of a corporation, which is proscribed and punishable by law" (Schur, 2001). Simpson menyatakan bahwa ada tiga ide pokok dari definisi Braithwaite mengenai kejahatan korporasi, yaitu: 1) Pertama, tindakan ilegal dari korporasi dan agen-agennya berbeda dengan perilaku kriminal kelas sosioekonomi bawah dalam hal prosedur administrasi. Karenanya, yang digolongkan kejahatan korporasi tidak hanya tindakan kejahatan atas hukum pidana, tetapi juga pelanggaran atas hukum perdata dan administrasi.; 2) Kedua, baik korporasi (sebagai "subyek hukum perorangan "legal persons") dan perwakilannya termasuk sebagai pelaku kejahatan (as illegal actors), dimana dalam praktek yudisialnya, bergantung pada antara lain kejahatan yang dilakukan, aturan dan kualitas pembuktian dan penuntutan; dan 3) Ketiga, motivasi kejahatan yang dilakukan korporasi bukan bertujuan untuk keuntungan pribadi, melainkan pada pemenuhan kebutuhan dan pencapaian keuntungan organisasional. Tidak menutup kemungkinan motif tersebut ditopang pula oleh norma operasional (internal) dan sub-kultur organisasional.

Kejahatan korporasi mungkin tidak terlalu sering kita sering dalam pemberitaanpemberitaan kriminil di media (Sudarto, 1981). Aparat penegak hukum, seperti kepolisian juga pada umumnya lebih sering menindak aksi-aksi kejahatan konvensional yang secara nyata dan faktual terdapat dalam aktivitas sehari-hari masyarakat. Ada beberapa beberapa faktor yang 
mempengaruhi hal ini, antara lain (E.Z. Leasa, 2010): Pertama, kejahatan-kejahatan yang dilaporkan oleh masyarakathanyalahkejahatan-kejahatankonvensional. Artikel juga menunjukkan bahwa aktivitas aparat kepolisian sebagian besar didasarkan atas laporan anggota masyarakat, sehingga kejahatan yang ditangani oleh kepolisian juga turut bersifat konvensional. Kedua, pandangan masyarakat cenderung melihat kejahatan korporasi atau kejahatan kerah putih bukan sebagai hal-hal yang sangat berbahaya,dan juga turut dipengaruhi. Ketiga, pandangan serta landasan hukum menyangkut siapa yang diakui sebagai subjek hukum pidana dalam hukum pidana Indonesia. Keempat, tujuan dari pemidanaan kejahatan korporasi adalah lebih kepada agar adanya perbaikan dan ganti rugi, berbeda dengan pemidanaan kejahatan lain yang konvensional yang bertujuan untuk menangkap dan menghukum. Kelima, pengetahuan aparat penegak hukum menyangkut kejahatan korporasi masih dinilai sangat minim, sehingga terkadang terkesan enggan untuk menindaklanjutinya secara hukum. Keenam, kejahatan korporasi sering melibatkan tokoh-tokoh masyarakat dengan status sosial yang tinggi. Hal ini dinilai dapat mempengaruhi proses penegakan hukum.

Kitab Undang-undang Hukum Pidana Indonesia memang hanya menetapkan bahwa yang menjadi subjek tindak pidana adalah orang persorangan (legal persoon). Pembuat undang-undang dalam merumuskan delik harus memperhitungkan bahwa manusia melakukan tindakan di dalam atau melalui organisasi yang, dalam hukum keperdataan maupun di luarnya (misalnya dalam hukum administrasi), muncul sebagai satu kesatuan dan karena itu diakui serta mendapat perlakuan sebagai badan hukum atau korporasi (Barda Nawawi Arief, 1996). Berdasarkan KUHP, pembuat undang-undang akan merujuk pada pengurus atau komisaris korporasi jika mereka berhadapan dengan situasi seperti itu. Sehingga, jika KUHP Indonesia saat ini tidak bisa dijadikan sebagai landasan untuk pertanggungjawaban pidana oleh korporasi, namun hanya dimungkinkan pertanggungjawaban oleh pengurus korporasi.

Hal ini bisa kita lihat dalam pasal 398 KUHP yang menyatakan bahwa jika seorang pengurus atau komisaris perseroan terbatas, maskapai andil Indonesia atau perkumpulan korporasi yang dinyatakan dalam keadaan pailit atau yang diperintahkan penyelesaian oleh pengadilan, diancam dengan pidana penjara paling lama satu tahun 4 (empat) bulan: 1. jika yang bersangkutan turut membantu atau mengizinkan untuk melakukan perbuatan- perbuatan yang bertentangan dengan anggaran dasar, sehingga oleh karena itu seluruh atau sebagian besar dari kerugian diderita oleh perseroan, maskapai, atau perkumpulan...(dan seterusnya). Meskipun KUHP Indonesia saat ini tidak mengikutsertakan korporasi (Frans Maramis, 1994) sebagai subyek hukum yang dapat dibebankan pertanggungjawaban pidana, namun korporasi mulai diposisikan sebagai subyek hukum pidana dengan ditetapkannya Undang-undang Nomor 7/Drt/1955 tentang Pengusutan, Penuntutan dan Peradilan Tindak Pidana Ekonomi.

Kemudian kejahatan korporasi juga diatur dan tersebar dalam berbagai undang-undang khusus lainnya dengan rumusan yang berbeda-beda mengenai "korporasi", antara lain termasuk pengertian badan usaha, perseroan, perusahaan, perkumpulan, yayasan, perserikatan, organisasi, dan lain-lain, seperti: (Jimmy Tawalujan, 2012): 1) Undang-undang Nomor 11/PNPS tahun 1964 tentang Pemberantasan Kegiatan Subversi; 2) Undang-undang Nomor 31 tahun 1999 jo. Undang-undang Nomor 21 tahun 2002 tentang Pemberantasan Tindak Pidana Korupsi; 3) Undang-undang Nomor 38 tahun 2004 tentang Jalan; 4) Undang-undang Nomor 31 tahun 2004 Jo. Undang-undang Nomor 45 tahun 2009 tentang Perikanan; 5) Undangundang Nomor 32 tahun 2009 tentang Perlindungan dan Pengelolaan Lingkungan Hidup; 6) Undang-undang Nomor 8 tahun 2010 tentang Pencegahan Dan Pemberantasan Tindak Pidana Pencucian Uang; 7) Undang-undang Nomor 18 tahun 2013 tentang Pencegahan Dan Pemberantasan Perusakan Hutan;

Di Indonesia, mempidanakan kejahatan korporasi adalah Undang-undang Nomor 32 tahun 2009 tentang Perlindungan dan Pengelolaan LingkunganHidup. Hal ini dapat dilihat dari 11 isi Pasal 116 ayat (1) yang mengadopsi doktrin strict liability dan Pasal 116 ayat (2) yang mengadopsi doktrin vicarious liability. Berdasarkan sistem hukum pidana di Indonesia pada saat ini terdapat 3 bentuk pertanggungjawaban pidana dalam kejahatan korporasi berdasarkan regulasi yang sudah ada, yaitu dibebankan pada korporasi itu sendiri, seperti diatur dalam 
Pasal 65 ayat 1 dan 2 Undang-undang Nomor 38 tahun 2004 tentang Jalan. Kemudian dapat pula dibebankan kepada organ atau pengurus korporasi yang melakukan perbuatan atau mereka yang bertindak sebagai pemimpin dalam melakukan tindak pindana, seperti yang diatur dalam pasal 20 ayat 2 Undang-undang Nomor 31 tahun 1999 tentang Tindak Pidana Korupsi dan Undang-undang Nomor 31 tahun 2004 tentang Perikanan. Kemudian kemungkinan berikutnya adala dapat dibebankan baik kepada pengurus korporasi sebagai pemberi perintah atau pemimpin dan juga dibebankan kepada koorporasi, contohnya seperti dalam UU Tipikor.

Perkembangannya guna mengisi kekosongan hukum dalam hal penanganan perkara tindak pidana korporasi, Mahkamah Agung telah menerbitkan Peraturan Mahkamah Agung Republik Indonesia Nomor 13 Tahun 2016 tentang Tata Cara Penanganan Perkara Tindak Pidana Oleh Korporasi (Perma 13/2016). Pasal 1 angka 1 Perma 13 menyatakan bahwa Korporasi adalah kumpulan orang dan/atau kekayaan yang terorganisir, baik merupakan badan hukum maupun bukan badan hukum. Perma 13/2016 ini juga telah mengisi kekosongan hukum yang bilamana terjadi tindak pidana korporasi yang melibatkan perusahaan grup. Perma 13/2016 juga telah memberikan suatu definisi tentang Tindak Pidana Korporasi, yakni "tindak pidana yang dapat diminta pertanggungjawaban pidana kepada korporasi sesuai dengan undang-undang yang mengatur tentangkorporasi. Perma 13/2016 juga dengan tegas telah mengadopsi doktrin vicarious liability sebagaimana Pasal 3 Perma 13/2016 yang menyatakan: "Tindak pidana oleh Korporasi merupakan tindak pidana yang dilakukan oleh orang berdasarkan hubungan kerja, atau berdasarkan hubungan lain, baik sendiri- sendiri maupun bersama-sama yang bertindak untuk dan atas nama Korporasi di dalam maupun di luar Lingkungan Korporasi." Perma 13/2016 ini merupakan suatu terobosan yang bisa dibilang inovatif dari Mahkamah Agung guna mengisi kekosongan hukum positif yang selama ini menjadi kendala bagi penegak hukum untuk menangani perkara pidana korporasi. Selain mengatur sedikit konsepsi tentang tindak pidana korporasi, Perma 13/2016 juga banyak mengatur tentang hukum acara dari tahapan penyelidikan hingga putusan yang selama ini tidak diatur dalam KUHAP.

Salah satu problem yang dihadapi konsep pidana tradisional mengenai tanggung jawab pidana berkenaan dengan dengan pertanggungjawaban korporasi. M. Yahya Harahap memberikan beberapa pendapatnya mengenai permasalahan pokok dalam pertanggungjawaban pidana oleh korporasi, antara lain (M. Yahya Harahap, 2013): 1) Berkenaan dengan kedudukan khusus korporasi (special position of corporation). Semua orang mengetahui kedudukan khusus korporasi atau Perseroan adalah badan hukum (legal person). Keberadaannya bukan manusia atau "natural person". Oleh karena itu, tidak bisa bertindak dan tidak memiliki kesadaran kehendak. Kesadaran dan perbuatannya, hanya melalui direksi atau pegawainya. Pertanyaan yang timbul dari keadaan ini, apakah pertanggungjawaban pidana pengurus korporasi sebagai natural person dapat diperluas kepada korporasi sebagai badan hukum (legal person)? 2) Permasalahan pokok yang laim, kalau hukum tidak membolehkan atau menutup pertanggungjawaban pidana menjangkau korporasi atas perbuatan pidana yang dilakukan dewan direksi atau pejabatnya, berarti hukum membuka pintu dan peluang selebar-lebarnya bagi pengurus korporasi mempergunakan korporasi sebagai kendaraan melakukan kejahatan. 3) Semakin meluasnya tindakan kejahatan yang tidak hanya bersifat mala in se tetapi sudah meluas meliputi berbagai segi kehidupan yang membutuhkan peraturan tindak pidana yang bersifat mala in prohibita. Maka demi untuk mewujudkan ketertiban yang dapat menjamin keselamatan umum, diperlukan konsep keadilan yang lebih canggih (sophisticated). Salah satu konsep yang dianggap dapat menjembataninya adalah pertanggungjawaban pidana korporasi.

Korporasi sebagai badan hukum sudah tentu memiliki identitas hukum tersendiri. Identitas hukum suatu korporasi atau perusahaan terpisah dari identitas hukum para pemegang sahamnya, direksi, maupun organ- organ lainnya. Dalam kaidah hukum perdata (civil law), jelas ditetapkan bahwa suatu korporasi atau badan hukum merupakan subjek hukum perdata dapat melakukan aktivitas jual beli, dapat membuat perjanjian atau kontrak dengan pihak lain, 
serta dapat menuntut dan dituntut di pengadilan dalam hubungan keperdataan. Para pemegang saham menikmati keuntungan yang diperoleh dari konsep tanggung jawab terbatas, dan kegiatan korporasi berlangsung terus-menerus, dalam arti bahwa keberadaannya tidak akan berubah meskipun ada penambahan anggota-anggota baru atau berhentinya atau meninggalnya anggota-anggota yang ada. Namun sampai saat ini, konsep pertanggungjawaban pidana oleh korporasi sebagai pribadi (corporate criminal liability) merupakan hal yang masih mengundang perdebatan. Banyak pihak yang tidak mendukung pandangan bahwa suatu korporsi yang wujudnya semu dapat melakukan suatu tindak kejahatan serta memiliki criminal intent yang melahirkan pertanggungjawaban pidana (Muladi dan Priyatno Dwidja, 2010).

Di samping itu, mustahil untuk dapat menghadirkan di korporasi dengan fisik yang sebenarnya dalam ruang pengadilan dan duduk di kursi terdakwa guna menjalani proses peradilan. Baik dalam sistem hukum common law maupun civil law, sangat sulit untuk dapat mengatribusikan suatu bentuk tindakan tertentu (actus reus atau guilty act) serta membuktikan unsur mens rea, (criminal intent atau guilty mind) dari suatu entitas abstrak seperti korporasi. DiIndonesia, meskipun undang-undang diatas dapat dijadikan sebagai landasan hukum untuk membebankan criminal liability terhadap korporasi, namun Pengadilan Pidana sampai saat ini terkesan enggan untuk mengakui dan mempergunakan peraturan-peraturan tersebut. Hal ini dapat dilihat dari sedikitnya kasus-kasus kejahatan korporasi di pengadilan dan tentu saja berdampak pada sangat sedikitnya keputusan pengadilan berkaitan dengan kejahatan korporasi Akibatnya tidak ada ada acuan yang dapat dijadikan sebagai preseden bagi lingkunganperadilandiIndonesia.Duakasusyang muncul di peradilan sampai dengan saat ini hanya berkaitan dengan pelanggaran lingkungan hidup.

\section{B. Metodologi Penelitian}

Penelitian hukum adalah suatu proses untuk menemukan aturan hukum, prinsip-prinsip hukum, maupun doktrin-doktrin hukum guna menjawab isu hukum yang dihadapi (Marzuki, 2007). Metode penelitian hukum adalah sebagai cara kerja ilmuwan yang salah satunya ditandai dengan penggunaan metode. Secara harfiah mula-mula metode diartikan sebagai suatu jalan yang harus ditempuh menjadi penyelidikan atau penelitian berlangsung menurut suatu rencana tertentu (Johny Ibrahim, 2006). Metode penelitian hukum merupakan suatu cara yang sistematis dalam melakukan sebuah penelitian. Penelitian hukum merupakan suatu kegiatan ilmiah, yang didasarkan pada metode, sistematika dan pemikiran tertentu, yang bertujuan untuk mempelajari satu atau beberapa gejala hukum dengan cara menganalisisnya. Tipe penelitian ini adalah penelitian hukum yang bersifat normatif dengan menggunakan 2 (dua) pendekatan antara lain Pertama. Pendekatan undang-undang (statute approach), yaitu yang dilakukan dengan menelaah semua undang-undang dan regulasi yang bersangkut paut dengan isu hukum yang ditangani. Pendekatan perundang-undangan ini akan membuka kesempatan bagi peneliti untuk mempelajari adakah konsistensi dan kesesuaian antar satu undang-undang dengan undang-undang lainya atau antara undang-undang dengan undang-undang dasar. Kedua pendekatan kasus (case approach) yaitu pendekatan yang dilakukan dengan cara melakukan telaahan terhadap kasus-kasus yang berkaitan dengan isu hukum yang dihadapi dan asas hukum yakni asas restorative justice dengan kepastian hukum dan keadilan.

\section{Hasil dan Pembahasan}

Perumusan sanksi pidana bagi korporasi yang dirumuskan secara tunggal akan muncul manakala pembaca masih berpikiran tradisional dimana tidak mengakui adanya pidana mati dan pidana penjara atau kurungan yang diterapkan terhadap korporasi. Singkatnya, permasalan mengenai perumusan pidana tunggal ini akan muncul manakala pembaca menilai bahwa pidana mati, pidana penjara dan pidana kurungan tidak dapat diterapkan bagi korporasi. Jadi, apabila demikian adanya maka hanya pidana denda yang dapat diterapkan bagi korporasi. Permasalahan tersebut akan tercermin dalam pertanyaan, sanksi pidana lain apakah yang dapat diterapkan terhadap korporasi manakala pidana denda tidak dibayar oleh korporasi? Apabila pidana denda ini dijatuhkan terhadap orang perseorangan (manusia alamiah) tidak akan 
menimbulkan suatu masalah yang berarti, oleh karena dalam pasal 30 KUHP sudah diatur dengan jelas bagaimana jika denda tidak dibayar "dapat dikenakan pidana kurungan pengganti denda". Sebaliknya, dengan diaturnya korporasi sebagai subjek hukum pidana maka ketentuan semacam ini sudah tentu tidak dapat diterapkan bagi korporasi (selama beranggapan bahwa"corporate death penalty" dan "corporate imprisonment" tidak dapat diterapkan bagi korporasi). Berbeda dengan pandangan yang sudah menilai "corporate imprisonment" atau pidana penjara atau pidana kurungan dapat diterapkan terhadap korporasi maka "corporate imprisonment" yang dalam hal ini adalah "pencabutan seluruh atau sebagian hak-hak tertentu atau penghapusan seluruh atau sebagian keuntungan tertentu" dapat dijadikan alternatif sanksi manakala pidana denda tidak dibayar oleh korporasi.

Singkatnya, apabila pidana denda tidak dibayar oleh korporasi, maka tidak ada sanksi pengganti atau alternatif sanksi lain yang dapat diterapkan terhadap suatu korporasi yang melakukan tindak pidana. Hal ini dikarenakan sampai dengan saat ini tidak ada ketentuan atau hukum yang mengatur mengenai masalah ini. Termasuk pula didalam undang-undang khusus atau hukum pidana khusus seperti Undang-Undang No. 31 tahun 1999 sebagaimana telah diubah oleh Undang-undang No. 20 tahun 2001 Tentang Pemberantasan Tindak Pidana Korupsi ataupun dalam undang-undang pencucian uang terbaru yaitu Undang-Undang No. 8 tahun 2010 Tentang Pencegahan Dan Pemberantasan Tindak Pidana Pencucian yang tidak diatur alternatif sanksi lain manakala pidana denda tidak dibayar oleh korporasi. Oleh sebab itu, tidaklah berlebihan apabila dikatakan bahwa dalam pengaturan mengenai jenis sanksi pidana yang dapat diterapkan terhadap korporasi mengalami kekosongan hukum (rechtsvacuum).

Pidana tambahan berupa pencabutan hak-hak tertentu sesuai dengan ketentuan pasal 10 poin $\mathrm{b}$ angka 1 KUHP yang mengatur mengenai pencabutak hak-hak tertentu yang penjabarannya diatur dalam Pasal 35 KUHP tidak dapat dikenakan pada korporasi oleh karena hak- hak tersebut hanya melekat pada manusia alamiah. Adapun ketentuan pasal 35 KUHP berbunyi: Hak-hak terpidana yang dapat dicabut dengan putusan hakim dalam hal-hal yang ditentukan dalam kitab undang-undang ini, atau dalam aturan umum yang lain, ialah: 1) Hak memegang jabatan pada umumnya atau jabatan yang tertentu; 2) Hak memasuki Angkatan Bersenjata; 3) Hak memilih dan dipilih dalam pemilihan yang diadakan berdasarkan aturanaturan umum; 4) Hak menjadi penasihat hukum atau pengurus atas penetapan pengadilan, hak menjadi wali, wali pengawas, pengampu atau pengampu pengawas, atas orang yang bukan anak sendiri; 5) Hak menjalankan kekuasaan bapak, menjalankan perwalian atau pengampuan atas anak sendiri.

Berdasarkan ketentuan diatas dapat dilihat bahwa pencabutan hak memegang jabatan, memasuki Angkatan Bersenjata, memilih dan dipilih dalam pemilihan, menjadi penasihat hukum dan lain sebagainya merupakan hak yang hanya melekat pada manusia alamiah. Oleh sebab itu, ketentuan mengenai pencabutan hak-hak tertentu tidak dapat diterapkan terhadap korporasi karena hak-hak tersebut hanya melekat pada manusia alamiah. Selain itu, sama dengan pidana tambahan berupa pencabutan hak-hak tertentu sebagaimana dikemukakan diatas, pidana tambahan berupa perampasan barang-barang tertentu sebagaimana diatur dalam pasal 10 poin b angka 2 tidak dapat diterapkan terhadap korporasi. Hal ini dikarenakan dalam pasal 39 KUHP yang mengatur mengenai perampasan dan penyitaan disebutkan dengan tegas bahwa: (1) Barang-barang kepunyaan terpidana yang diperoleh dengan kejahatan atau yang dengan sengaja digunakan untuk melakukan kejahatan, dapat dirampas. (2) Dalam hal pemidanaan karena kejahatan yang dilakukan dengan tidak sengaja atau karena pelanggaran, dapat juga dijatuhkan putusan perampasan berdasarkan hal-hal yang ditentukan dalam undangundang. (3) Perampasan dapat dilakukan terhadap orang yang bersalah yang oleh hakim diserahkan kepada pemerintah, tetapi hanya atas barang-barang yang telah disita.

Berdasarkan ketentuan pasal 39 KUHP tersebut, dapat dilihat bahwa perampasan barang hanya dapat dilakukan terhadap barang yang diperoleh dengan kejahatan, barang yang digunakan dalam melakukan kejahatan, barang tersebut harus milik terpidana, hanya terbatas 
pada benda berwujud dan perampasan hanya dapat dilakukan terhadap barang yang telah disita. Ruanglingkup perampasan barang sebagaimana diatur dalamn pasal 39 KUHP tersebut dapat dikategorikan sebagai perampasan yang sempit. Dikatakan demikian karena ruanglingkup perampasan barang sebagaimana diatur dalam pasal 39 sangat sempit dan dalam perkembangannya dewasa ini dinilai tidak cukup dalam rangka mencegah dan memberantas tindak pidana terlebih lagi bagi tindak pidana korporasi. Oleh sebab itu, ketemtuan ini tidak dapat diterapkan terhadap korporasi.

Mengutip kembali pernyataan sebelumnya yang menyatakan bahwa dalam merumuskan sanksi pidana didalam KUHP dikenal dengan sistem dua jalur (double track system) yaitu sebuah stelsel pemidanaan disamping penjatuhan sanksi pidana dikenal juga tindakan yang dapat dikenakan kepada pelaku tindak pidana. Mengenai tindakan yang dapat dikenakan terhadap pelaku tindak pidana ini, diatur secara tegas dalam pasal 44 ayat (2) KUHP yang berbunyi: Bila ternyata perbuatan itu tidak dapat dipertanggungkan kepadanya karena pertumbuhan jiwanya cacat atau terganggu karena penyakit, maka hakim dapat memerintahkan supaya orang itu dimasukkan ke rumah sakit jiwa, paling lama satu tahun sebagai masa percobaan" dan dalam pasal 45 yang berbunyi: “...memerintahkan supaya yang bersalah itu dikembalikan kepada orang tuanya, walinya atau pemeliharanya, tanpa dikenakan suatu pidana apa pun; atau memerintahkan supaya yang bersalah itu diserahkan kepada pemerintah tanpa pidana..."

Berdasarkan ketentuan tersebut, jelas bahwa semua tindakan sebagaimana diatur dalam pasal 44 ayat (2) dan pasal 45 diatas hanya ditunjukan kepada manusia alamiah dan tidak dapat diterapkan bagi suatu korporasi. Berdasarkan hal-hal tersebut diatas, dapat disimpulkan bahwa pengaturan atau perumusan sanksi pidana bagi korporasi dirumuskan secara tunggal. Oleh sebab itu, dalam rangka menjawab jenis sanksi pidana lain apa yang dapat diterapkan terhadap korporasi, penulis akan mengutip pendapat yang dikemukakan oleh Suprapto yang menyatakan bahwa hukuman yang dapat dikenakan pada perusahan (dalam hal ini korporasi) adalah: 1) Penutupan seluruhnya atau sebagian perusahan si terhukum untuk waktu tertentu; 2) Pencabutan seluruhnya atau sebagian fasilitas-fasilitas tertentu yang telah atau dapat diperolehnya dari pemerintah oleh perusahan selama waktu tertentu; dan 3) Penempatan perusahan di bawah pengampuan selama waktu tertentu. Dalam Pasal 18 ayat (1) UndangUndang Nomor 31 Tahun 1999 yang dapat dijadikan pidana pokok untuk korporasi atau setidak-tidaknya sebagai pidana tambahan yang dapat dijatuhkan mandiri. Apabila pidana penjara merupakan pidana pokok untuk "orang", maka pidana pokok yang dapat diidentikkan dengan pidana perampasan kemerdekaan adalah sanksi berupa "penutupan perusahan atau korporasi untuk waktu tertentu" atau "pencabutan hak ijin usaha.

Perumusan pidana pokok yang lain selain denda sebagaimana sering dirumuskan sekarang ini dalam beberapa undang-undang yang tersebar diluar KUHP, dapat saja dilakukan oleh karena menurut Barda Nawawi Arief, jenis pidana atau tindakan terhadap korporasi dapat berupa: a) Financial Sanction (Financial Sanction dalam hal ini misalnya denda, peningkatan pajak yang harus dibayar dan lain sebagainya); b) Structural Sanctions; c) Restriction Entrepreneurialactivities (Restriction Entrepreneurialactivities dalam hal ini misalnya pembatasan kegiatan usaha, pembubaran korporasi); d) Stigmatising Sanctions; e) Mengingat korporasi atau perusahaan adalah "bisnis kepercayaan" menurut hemat penulis mengutip pendapat Brickey yang menyatakan bahwa: “...pengumuman keputusan hakim (publication), merupakan sanksi yang sangat ditakuti oleh korporasi..." nampaknya Stigmatising Sanctions dapat menjadi sanksi yang paling ditakuti oleh korporasi.

Pengaturan korporasi sebagai subjek hukum pidana yang dinilai dapat melakukan suatu tindak pidana dan dapat mempertanggungjawabkan perbuatannya secara pidana didalam Undang- Undang Nomor 8 tahun 2010 tentang Pencegahan dan Pemberantasan Tindak Pidana Pencucian Uang tepatnya dalam pasal pasal 7 sampai dengan pasal 9 yang berbunyi: Pasal 7: (1) Pidana pokok yang dijatuhkan terhadap Korporasi adalah pidana denda paling banyak Rp. 100.000.000.000,00 (seratus miliar rupiah). (2) Selain pidana denda sebagaimana dimaksud pada ayat (1), terhadap Korporasi juga dapat dijatuhkan pidana tambahan berupa: a. 
Pengumuman putusan hakim; b. Pembekuan sebagian atau seluruh kegiatan usaha Korporasi; c. Pencabutan izin usaha; d. Pembubaran dan/atau pelarangan Korporasi; e. Perampasan aset Korporasi untuk negara; dan/atau f. Pengambilalihan Korporasi oleh negara.

Pasal 8 meyatakan bahwa dalam hal harta terpidana tidak cukup untuk membayar pidana denda sebagaimana dimaksud dalam Pasal 3, Pasal 4, dan Pasal 5, pidana denda tersebut diganti dengan pidana kurungan paling lama 1 (satu) tahun 4 (empat) bulan". Pasal 9 meyatakan bahwa (1) Dalam hal Korporasi tidak mampu membayar pidana denda sebagaimana dimaksud dalam Pasal 7 ayat (1), pidana denda tersebut diganti dengan perampasan Harta Kekayaan milik Korporasi atau Personil Pengendali Korporasi yang nilainya sama dengan putusan pidana denda yang dijatuhkan. (2) Dalam hal penjualan Harta Kekayaan milik Korporasi yang dirampas sebagaimana dimaksud pada ayat (1) tidak mencukupi, pidana kurungan pengganti denda dijatuhkan terhadap Personil Pengendali Korporasi dengan memperhitungkan denda yang telah dibayar.

Berdasarkan ketentuan tersebut, dapat dilihat bahwa pengaturan pidana bagi korporasi dalam Undang-Undang No. 08 tahun 2010 tidak dirumuskan secara tunggal dan dinilai jauh lebih efektif dan evisien dalam rangka memberantas tindak pidana korupsi (dan pencucian uang) jika dibandingkan dengan ketentuan yang ada dalam Undang-Undang No. 31 tahun 1999 sebagaimana telah diubah oleh Undang-Undang No. 20 tahun 2001 tentang Pemberantasan Tindak Pidana Korupsi. Oleh sebab itu, ketentuan-ketentuan trsebut dapat dijadikan acuan dalam merumuskan pidana pengganti denda jika denda tidak dibayar oleh korporasi.

\section{Penutup}

Pertimbangan dampak yang dapat ditimbulkan oleh kejahatan korporasi baik bagi masyarakat, perekonomian, pemerintahan dan aspek-aspek lainnya yang berbahaya, bahkan lebih serius dibandingkan dengan dampak yang ditimbulkan oleh bentuk-bentuk kejahatan yang konvensional, maka harus ada konsistensi dan landasan yang solid dalam hukum untuk dapat membebankan pertanggungjawaban pidana kepada korporasi. Dalam berbagai harus terdapat pengaturan menyangkut pertanggungjawaban ini. Selain itu, diperlukan perhatian studi yang lebih mendalam, baik di kalangan akademis, profesional maupun aparat penegak hukum, guna membangun suatu kerangka teoritis bagi pertanggungjawaban pidana korporasi. Hal ini hendaknya diimbangi pula dengan upaya peningkatan kualitas dan kemampuan para penegak hukum yang akan menerapkannya. Mereka harus mampu dan kreatif untuk melakukan terobosan-terobosan hukum.

\section{Daftar Pustaka}

Barda Nawawi Arief, Batas-Batas Kemampuan Hukum Pidana Dalam Penanggulangan Kejahatan, Makalah Seminar Nasional Pendekatan Non- Penal Dalam Penanggulangan Kejahatan, Semarang, 1996.

Bismar Nasution, Tindak Pidana Korporasi, Disampaikan pada Seminar Sehari "Good Corporate Governance (GCG) PT. Perusahaan Listrik Negara (Persero) dan Anak Perusahaan," diselenggarakan oleh PT. Perusahaan Listrik Negara, Batam, tanggal 29 Agustus 2019.

E.Z. Leasa, Penerapan Sanksi Pidana Dan Sanksi Tindakan (Double Track System) Dalam Kebijakan Legislasi, Jurnal Sasi Vol. 16 No. 4 Bulan Oktober - Desember 2010.

Frans Maramis, Perbandingan Hukum Pidana, Pustaka Sinar Harapan, Jakarta, 1994.

Henry Campbell Black, Black's Law Dictionary, West Publishing Co., St. Paul, Minnessota, 1990.

Hyman Gross, A Theory of Criminal Justice, Oxford University Press, New York, 1979.

Jimmy Tawalujan, Pertanggungjawaban Korporasi Terhadap Korban Kejahatan, Lex Crimen Vol.I/No.3/Jul-Sep/2012.

M. Yahya Harahap, Hukum Perseroan Terbatas, Sinar Grafka, Jakarta, 2013. 
Muladi dan Priyatno Dwidja, Pertanggungjawaban Pidana Korporasi, Kencana, Jakarta, 2010.

Schur, Edwin M., Crime Without Victims: Deviant Behavior and Public Policy, Prentice Hall, Inc. Englewood Cliffs, NJ, 2001.

Singgih, Kejahatan Korporasi yang Mengerikan, Pusat Studi Hukum Bisnis Fakultas Hukum Universitas Pelita Harapan, Tangerang, 2005.

Sudarto, Hukum dan Hukum Pidana, Alumni, Bandung, 1981.

Suhariyono AR, Penentuan Sanksi Pidana Dalam Suatu Undang-Undang, Jurnal Legislasi Indonesia. Vol. 6 No. 4 - Desember 2009. 